\title{
Discursive investigation into John's internalised spirit identity and its implication
}

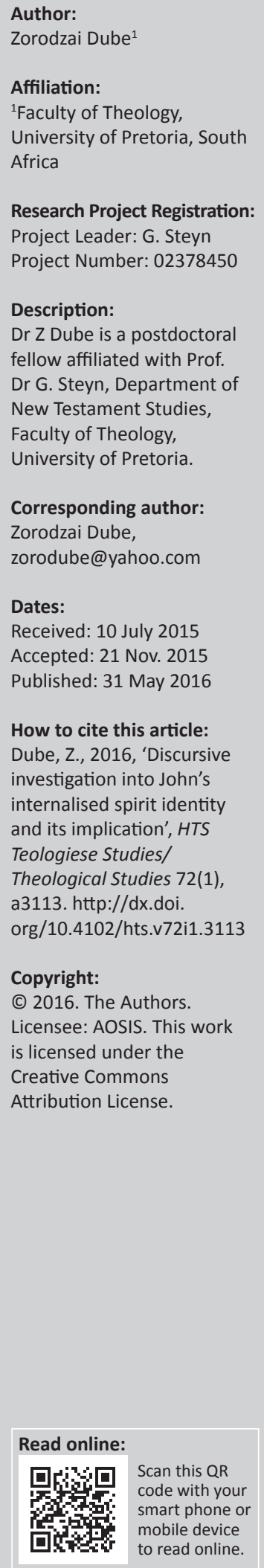

What does it mean to live in a society where everything good is located within one ethnicity, and geography? In reading the gospel of John, one gets the impression that faithful disciples, the Holy Spirit and morality are exclusively located within the Johannine community and can only permeate to the outside through the good work of the insiders - the disciples. Everything is asymmetric - morality, ideal disciples and good virtues - these originate from within John's community. Outside John's community, it is darkness that awaits the illuminating lights of John's disciples, without which they will remain in perpetual darkness. Despite recent theories that position John as a missionary and an open community, still it does not remove the asymmetric nature of the gospel. The study builds on views inspired by scholars such as Jonathan Draper (1992:13) to argue that John used the Holy Spirit to naturalise identities. From this perspective and if read from the South African context of racism, ethnicity and gender, John makes the reader think about the consequences and implications of exclusive social boundaries.

\section{Introduction}

A festschrift of the church history, Professor Norman Duncan who is a long-serving faculty member at the University of Pretoria, necessarily grapples with challenging questions facing our South African communities. Personally, I know Professor Duncan as a vocal advocate for justice, peace and equality in South Africa. In terms of identity, Duncan is a white man of Scottish descent, which easily assigns him certain material privileges based on his ethnicity, yet his calling as a pastor and church historian places him at a queer position where he spent most of his academic career querying particular privileges based on race, ethnicity and gender.

The text of John 8:44-46 is a good starting point to discuss ascribed and naturalised privileges associated with being an insider and to reflect the discomforts associated with maintaining such binary categories. The text of John 8:44-47 reminds us that sometimes the bible presents negative narratives as examples of social pitfalls to be avoided. The text is illustrative of a community that rigidly maintains its status as insiders; enjoying the benefits and privileges associated with such social positions. From the experiences of race, ethnicity and gender in South Africa, the verses in John 8:44-46 are illustrative of social pitfalls that need to be avoided. The verses (vv. 44-46), written in reference to 'the Jews', the Johannine Jesus, says:

You are of your father the devil, and you want to do the desires of your father. He was a murderer from the beginning, and does not stand in the truth because there is no truth in him. Whenever he speaks a lie, he speaks from his own nature, for he is a liar and the father of lies. But because I speak the truth, you do not believe Me. (John 8:44-46)

In the verses, Jesus castigated the Jews and naturalised their identity. For the Johannine Jesus, the Jews - the outsiders, are incorrigibly or naturally evil because, like their father the devil - they are genetically evil; they are murderers and liars, speaking the truth is not part of their genetic makeup. This does not mean that John had nothing to do with the outsiders. For John, the outsiders are evil people who live in darkness; their hope is to believe and convert so that they can be included as insiders. John sees truth, morality and hope as flowing from the inside to the outside and not vis-à-vis. Truth is not multifaceted.

Learning about John's community from the history and experiences of South Africa reminds us of ethnic divisions whereby one ethnic group has social capital at the expense of the others. For example, John reminds us of ethnic groups that say, 'we talk with the blacks/whites/Zulus/ shona if...'. John sees clear binaries and only relaxes them when the outsiders agree or accept his terms and conditions. In the case of John, it was belief and conversion. In today's language, 
it is monopoly. In his Johannine narrow worldview, the outsiders should believe, convert, accept and follow because they are in darkness. From a South African perspective, reading Johannine discourse loudly reminds us of the naturalised categories of race, ethnicity and gender. The discourse about a race, tribe or sex that sees itself as better than the others is characteristic of the history of South Africa. How do you live in a society where a race, tribe or sex requires the others to change by speaking the language, change culture, personal names and change geography as condition to be accepted as an insider? Is it possible to challenge and dismantle the binaries from within or that one has to identify with the outsiders to collapse the binary superstructure? What are the identity complexities of living in an identity-structured and categorised society? I see these questions printed all over Norman Duncan's academic career.

\section{Naturalised identities in South Africa}

Naturalised identities ${ }^{1}$ are engraved labels ascribed to a group or ethnicity and are stereotypically and perpetually cast as true (Tong 2010:159). Kiong Tong, whose studies focus on generalised labels given to the Chinese in Asia, argues that sometimes people treat others based on generalised and stereotypical labels. The British social psychologist, Henri Tajfel (1982:1) in his various books dealt extensively with how identities are naturalised and categorised. Tajfel (1982:1) observes that social interactions are based on identities that are similar vis-à-vis dissimilar. Mostly, people with dissimilar identities are seen as outsiders or different from people who regard themselves as sharing similar characteristic traits - the insiders. Tajfel (1982:1) calls this process categorisation. However, recently Tajfel's (1982:1) idea of social categorisation has been modified and disputed by social theorists, such as Leslie McCall (2005:1771), who discovered that instead of fixed categories, identities intersect and mutate; they are malleable. Like any social phenomenon, identities are malleable depending on gender, race, class and geography. Thus, instead of fixed identities, we should talk about intersectional identities.

However, in my view and in reference to the South African context, Tajfel's (1982:1) social categorisation based on race, gender and sex is still prevalent. In South Africa, men still require their women to perform cultural duties including cooking and bearing children, especially male offspring. A majority of people still use their ethnic groups as the base category whilst relating to other tribes in matters such as marriage, friendship or employment. On a national level, colonial and apartheid labels that are used to refer to blacks as lazy, dishonest and non-achievers are still being nurtured in various sections of the society. Many times such overarching and generalised labels are not contested because they serve as idiosyncratic identity maps. Ironically and despite the end

\footnotetext{
1.Naturalised identity markers overlap with discussions about scientific racism, which developed during the modern period (1700 and $1900 \mathrm{CE})$. Scientific racism taught that black people, because of their skin colour, are naturally inferior, whilst white that black people, because of their skin colour, are naturally inferior, whilst white
people are superior. Hegel (translated 1977:104) says because black people are not people are superior. Hegel (translated 1977:104) says because black peopl
exposed to rationalism and science, their level of consciousness is low.
}

of apartheid era, studies show that people still define themselves based on racial and ethnic categories - black, white, Zulu or Ndebele. Jeremy Seeking (2007: p.n.) says 'South Africa remains deeply racialized, in cultural and social terms, as well as deeply unequal, in terms of the distribution of income and opportunities'. Similarly, Heribert Adam and Kogila Moodley (2013:18) say 'South Africa is not yet a racefree, colour blind society'.

Why are naturalised categories perpetual; why are they still functional as descriptive categories. Charles Tilly (2005:3) explains that social identity categories are functional labels they maintain and sustain exclusive categories of those who materially and socially benefit from such categorisation. In celebrating the academic life achievements of Professor Norman Duncan, I shall contribute by looking at the implications of using naturalised categories, with reference to John and South Africa. Concerning John, my investigation which agrees mostly with Jonathan Draper (1992:13) focuses on the discursive use of the Spirit, whilst in the section that relates to South Africa, I raise general questions that are connected to my discussion of John's gospel.

\section{Identity during the 1st century and in John}

With regards to John, who was possibly located in Ephesus (Thompson 1996:21), debate ensues concerning whether the community was inclusive or exclusive. The traditional voices, which I shall follow, are represented by Jonathan Draper (1992:13) - these are unanimous over the idea that the Johannine community was exclusive. Jonathan Draper (1992:13) characterises John's community as a group that had lost its founder - Jesus - simultaneously facing threats from outsiders. Draper suggests that the paraclete sayings, especially those in John 17 , function as boundary maintenance discourses to cut-off the community from the rest of the world. Only within the community does the Holy Spirit operate, whilst outside is sheer darkness (Draper 1992:27). Draper's ideas can be traced in Wayne Meeks (1993) (Barrett 1978:325²; Bultmann 1951:20; Dodd 1953:17; Dunn 2003:881; Hays 1996:40; Hegel 1807:13; Jervell 1996:30; Martyn 1979:90).

In contrast, the recent views see the gospel of John as an inclusive missional community - a view vehemently supported by Andreas Köstenburger (1998) in the book, The mission of Jesus and the Disciples in the Fourth Gospel, Michael Waldstein (1990) in the book, The mission of Jesus and the Disciples, D.G. van der Merwe (1998:115) in an article, John 17: Jesus Assigns His Mission to His Disciples, Marianus Pale Hera (2013), in the book, Christology and Discipleship in John 19, and Smit Guillaume (2015:255) in an article, Investigating John 13-17 as a missional narrative. As evidenced from the titles, the new voices interpret John as an open missional text, in which Jesus commissions his disciples. The meta-theory underpinning these writings, as Paul Anderson (1999:33) poignantly states, is the motif that God sent Jesus, who sends his disciples. Such a dense theological

2.For further discussion regarding the location and debate regarding philosophical influences about either Judaism or Hellenism, see Barrett (1978:325). 
canopy does not pill-off to allow the reader to understand the social dynamics within the Johannine community. Instead, the new voices put emphasis on the activities of God through Jesus and his disciples. In addition to the illustrated recent views, there are other recent voices that connected John's community to the political context during the 1st century, such as Richard J. Cassidy (1992:42), who thinks that John's gospel mimics the empire by presenting Jesus as the true divine Emperor vis-à-vis the Roman Emperor. A similar view is echoed by Per Jarle Bekke (2005:12).

As evaluation, overall, besides Richard Cassidy, the weakness of recent views is their tendency to emphasise a theological reading - reading John as a missional manual, in the process downplaying the ethnic conflict that glares from the pages of John. This is not to deny that John has a missional motif, but we must realise that the deployment of the disciples starts from within the Johannine community. Only within the community does the true disciples and the Holy Spirit reside; anything outside the community lurks in the region of darkness and requires the imperial gospel (Conway 2003:163). John focuses on the insiders, and whenever he looks outside, his intention is to duplicate the inside to the outside because there is nothing inherently good found in the outside. Arguably, John creates identity categories monitored and reinforced by the spirit.

\section{Discourse of social categories in John}

It is important to understand the social conflicts associated with John's community in order to appreciate how the Spirit functions in reinforcing social categories. With regards to this matter, Paul Anderson (1999:33) and Martin de Boer (2001) help us to unpack the identity contentions within John's community. Paul Anderson (1999:33) who investigated the meaning of the phrase 'having-sent-me-father' in John argues that John uses the typology of Moses to present Jesus as the new Moses. John's community follows Jesus, and therefore, the community identifies with the true prophet - Jesus and are destined for truth and happiness. As such, the Johannine community described itself with superlative adjectives vis-àvis the Jews who had not believed or had refused to be part of the Johannine community. The true Jews are those who follow the new Moses - Jesus. Martin de Boer (2001:156) gives a similar and more elaborate explanation saying the contention between the Johannine Jews and the other Jews was over the identity ' jew'. As such, John can be read as using the phrase 'the Jews' sarcastically to indict the Jews who had refused to accept Jesus as the Jewish Messiah. By rejecting Jesus, 'the Jews' ironically forfeited their own identity (Jn 19:15) 'because they have rejected the Johannine proclamation of Jesus as the promised Messiah of Israel' (De Boer 2001:156). They have indicted themselves because even Moses 'wrote about me (Jesus)' (Jn 5:46); by rejecting Jesus, they rejected Moses' testimony. The identity contention is attested to by Raymond Brown (1997), Bart Ehrman (2009) and Barnabas Lindars (1990).

\section{The Holy Spirit as identity marker}

Because ethnically and morphologically the believing Jews and the non-Jews were all Jews, John added another identity marker - true Jews are anatomically defined by the Spirit which is only found within the community. The Spirit is sent by Jesus; it is Jesus in his non-physical form. George Johnston (1970:149) remarks saying that, in John, the Spirit permeates everything such that the text looks like 'Montanist error'; the Spirit infuse beings, blurring the distance between the natural and the divine. The Spirit in-dwells inside the believers, becoming an internal substance. He becomes an indispensable identity marker, all social activities are measured on the basis of whether they are motivated or authorised by the Spirit. As John himself explains, in reference to the spirit, he is the Spirit of truth, who guides the believers in all truth (14:25). Within the community, the Spirit leads, comforts, teaches and gives remembrance. The Spirit resides with and inside the believers, stamping a crucial identity marker on the believers as 'the children of God' (1:12). The Spirit becomes the new fictive kinship marker as opposed to bloodline. The believers are 'not born of blood nor of the will of man, but of God' (1:13) (Borgen 1996:111) - making the spirit the source of his new fictive kinship. Those with the Spirit are predisposed to doing good, hence forming an inside community of the faithful disciples vis-à-vis the outsiders.

The outsiders are incorrigibly evil; they are sons and daughters of the devil who is anatomically evil, making the outsiders genetically and anatomically evil. It seems John is using the stoic concept of the sperma to imprint the idea that the outsiders are by nature, evil. In John 8:44-45, the devil is the father ( $\pi \alpha \tau \rho$ òs) meaning the original sperma/seed. The term $\pi \alpha \tau \rho$ ò $\varsigma$ is placed to conjure their anatomic identity of the outsiders as children of the devil and their immorality is anatomically traced to the devil. The devil was from the

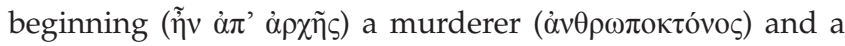
liar ( $\psi \varepsilon v ́ \sigma \tau\rceil \varsigma)$. Being children of the devil, the outsiders are conditioned to doing evil, to murder and to lie; they have an inherent desire ( $\left.\dot{\varepsilon} \pi, \theta v \mu \boldsymbol{i}_{\alpha}\right)$ ) to do according to their father - the devil.

In contrast, John identified his community members as people endowed with the divine seed - the Spirit, which makes them to abide and not to lie (Kelber 1996:132). To the Johannine believers, the Spirit is the new identity marker that conditions their good behaviour. Through several narratives, John illustrates how the in-dwelling Spirit is a new identity marker and not ethnicity. For example, the Nicodemus story (3:1) and the Samaritan woman story (4:1) illustrate how the spirit is the new community identity marker. The common pattern in these stories is the inability of the main characters - Nicodemus and the Samaritan woman, to comprehend the truth. Lack of understanding is characteristic of outsiders. In both stories, there is reference to being born from above, by water and spirit. Commenting on the Nicodemus story, Philo of Alexandria (leg.All.1.49, de virtue.171-72) (transl. Conybeare 1895:325), who used a platonic allegorical interpretation, says that the 'born from above' signifies a superior identity, which 
is different from the earthly genos. Thus, though Nicodemus is the teacher of the Jewish law, he failed to comprehend the meaning of birth by the spirit because he was an outsider and had no spirit. The Johannine Jesus emphasised, saying, 'Truly, truly, I say, unless one is born of water and the spirit, he cannot enter the kingdom of God'. Also, 'that which is born of flesh is flesh, and that which is born of spirit is spirit' (Jn 3:5). The Nicodemus story concluded with the Johannine Jesus mocking Nicodemus' lack of spiritual aptitude - a clear sign that Nicodemus was an outsider devoid of the inherent Spirit.

The Samaritan woman's story is equally illustrative. In addition to evoking gender questions, the story places the Spirit as the identity marker - those who were outside the community, like the Samaritan woman, were without the light or understanding (Brown 1988:39). Hence, being an outsider, the Samaritan woman was blind and did not comprehend the dawn of the new dispensation - the once-off opportunity for her and her community to enter the new kingdom. Clinging to her mundane identity of being a Samaritan, she exuded ignorance by asking invalid questions. The Johannine Jesus perceived her incorrigible blindness and quickly reminded her that she lacked, like Nicodemus, the Spirit to open her eyes and to understand.

\section{Implications of categories towards social cohesion in South Africa}

Celebrating the academic life of Norman Duncan through the experiences in South Africa makes the gospel of John an interesting read. John makes us wrestle with palpable categories of race, gender and ethnicity in South Africa. John makes us to ask the following questions:

- What are the implications of living in a society that is conscious of categories?

- What discourses are used to entrench and sustain the social categories of insider/outsider, black/white, Zulu/ foreigner as visible identity markers?

- Who benefits from sustaining and maintaining the binary categories?

With regards to the first question, the academic life of Norman Duncan testifies to the implications of living in a polarised, identity-conscious society. Like John, a society that lives in different spheres only knows each other through verbal stereotypes because there is no common history and identity, everything is superficial. With regards to John, we have noted that their only memory of the outsiders was through negative labels such as 'darkness', 'lack of truth' and 'children of the devil'. We are not told how the Jews perceive of their schismatic Christian brothers and sister but surely they must have had their own negative stereotypes towards their schismatic cousins. With regards to Norman Duncan, I am sure that even in his retirement, he grapples with one particular question that how can the South African history be narrated as a collective story instead of being cast as patches of ethnic memories. In my view, the starting question is whether we have common experiences or memories. Can the English descendants, Afrikaans descendants or African descendants look at the history or memories of other as part of their own memory? An important aspect that derives from John's community is that the moment an ethnic group denies the memories of the other or seeks to Hellenise the other, there is always resistance by the other and labelling.

Concerning the second question, which is what discourses are used to maintain and sustain the categories, in John we noted that labels such as 'the Jews' encapsulated all the negative things about being an outsider. Labels are not decorative titles; instead, they function as discursive references or codes. In South Africa, white is a code of being materially privileged whilst black is a code of violence, laziness, untrustworthy and other negative labels. Stories are told of white property owners who refused to rent their apartments to black people because of discursive labels dragged by being black. Similar reports are told concerning employment. The challenge is that codes only make sense to people who share the worldview, as such obliterating codes is a challenge. Further codes make one clandestine in the way one relates to the others; making one hypocritical. Instead of one to come clean and say I do not employ blacks in my company, surreptitious reasons such as lazy or not qualified are used. It is the task of theology to expose coded identities that sustain social categories.

The last question in reading John alongside South Africa is who benefits from the categories of race, ethnicity and gender. With regard to John, we noticed that the insiders benefited from the status core by viewing themselves with superlative labels. Therefore, we learn that power is associated with labelling; people with power maintain their status by maintaining the labels. For example, a black man who enjoys his wife cooking and preparing bathing water, would not entertain gender discussions. Equally, a white man who materially benefits merely by being white would not entertain narratives that suggest that blacks are equally capable. It is sad that in our theological faculties, theology avoids interrogating the manner in which it sustains and deploys imperial and masculine language. Theology still labels God as father, which as a masculine gender symbol. Equally, Jesus is portrayed as a blond white man, which perpetuates the narrative that Christianity is Western, thus perpetuating the myths that Jesus was European or white.

\section{Conclusion}

The study started by observing that the community of John, though entertaining a missionary motif, was hinged on the idea that only within the Johannine community power, morality (truth and faithfulness) and peace abide. This realisation makes us view John's community as a community that regarded itself in superlative adjective; meaning that others are good if only they copy, convert and follow John's model. Failure to follow, John would not hesitate to label outsiders as 'children of the devil' who are incorrigibly evil. What we witness in John are fixed categories with an imperial 
intent. Whilst celebrating the long academic life of Norman Duncan, the gospel of John makes us think about important questions concerning South Africa. Some of the questions are as follows: what are the implications of living in an identitycategorised society? Who benefits from such categories? What are the discourses that keep categories in place? There is no easy answer to each question but a multiple approach is needed. In the discussion, I suggest that theology should not be blind or hesitate to critique discourse of power monopoly, which reside, for instance in gender and race issues. Theology, a subject that starts with God should heal social chasms and bring people together and be prophetic whenever labels and codes are used to further categorise people in parochial labels of race, ethnicity and gender.

\section{Acknowledgements Competing interests}

The authors declare that they have no financial or personal relationships which may have inappropriately influenced them in writing this article.

\section{References}

Adam, H. \& Moodley, K., 2013, Imagined liberation: Xenophobia, citizenship and identity in South Africa, Germany and Canada, Sun Press, Stellenbosch.

Anderson, P., 1999, 'The having-sent-me father: Aspects of agency, encounter and irony in the Johannine father-son relationship', Semeia 85, 33-57.

Barrett, C.K., 1978, The gospel according to St John: An introduction with commentary notes on the Greek text, Westminster, Philadelphia.

Bekke, P.J., 2005, The lawsuit motif in John's gospel from new perspectives: Jesus Christ, crucified criminal and emperor of the world, Brill, Boston.

Borgen, P., 1996, 'The gospel of John and Hellenism: Some observation', in A Culpepper \& C. Black (eds.), Exploring the gospel of John: In Honour of D. Moody Smith, Westminster John Knox Press, Louisville.

Brown, R.E., 1988, The gospel and epistle of John: A concise commentary, The Liturgical Press, Collegeville.

Brown, R.E., 1997, An introduction to the New Testament, Anchor Bible, New York.

Bultmann, R., 1951, Theology of the New Testament, 2. vols, Charles Scribner's, New York.

Cassidy R.J., 1992, John's gospel in new perspective: Christology and the realities of roman power, Orbis, Maryknoll, New York.

Conway, C., 2003, "'Behold the man!" Masculine Christology in the Fourth Gospel', in S. Moore \& J. Anderson (eds.), New testament masculinities: Society of biblical literature 45, pp. 163-180, Society of Biblical Literature, Atlanta.
Conybeare, F.C., 1895, (Translator) Philo about the contemplative life, Clarendon Press, Oxford.

De Boer, M.C., 2001, 'The depiction of the Jews in John's Gospel: Matters of behaviour and identity', in R. Bieringer, D. Pollefeyt \& F. Vandecasteele (eds.), Anti-Judaism in the Fourth Gospel, pp. 141-157, Westminster John Knox, Louisville.

Dodd, C.H., 1953, Interpreting the Fourth Gospel, Cambridge University Press, Cambridge.

Draper, J., 1992, The sociological function of the spirit/paraclete in the farewell discourses in the Fourth Gospel, Neotestamentica 26(1), 13-29.

Dunn, J., 2003, Jesus remembered: Christianity in the making, vol. 1, Eerdmans, Grand Rapids.

Ehrman, B.D., 2009, Jesus, interrupted, HarperCollins, New York.

Guillaume, S., 2015, 'Investigating John 13-17 as a missional narrative', Stellenbosch Theological Journal 1, 255-271. http://dx.doi.org/10.17570/stj.2015.v1n1.a13

Hays, R.B., 1996, The Moral Vision of the New Testament: A contemporary introduction to NT Ethics, Harper, San Francisco.

Hegel, G.W.F., 1977, Phenomenology of the spirit, transl. A.V. Miller, Oxford Press, Oxford.

Hera, M.P., 2013, Christology and discipleship in John 17, Mohr Siebeck, Tübingen.

Jervell, J., 1996, The theology of acts of the apostles, Cambridge University Press, Cambridge.

Johnston, G., 1970, The spirit-paraclete in the gospel of John, Cambridge University Press, Cambridge.

Kelber, W., 1996, 'Metaphysics and marginality in John', in F. Segovia (ed.), 'Who is John?' Readers and readings of the Fourth Gospel, pp. 129-154, Society of Biblical Literature, Atlanta.

Köstenburger, A., 1998, The mission of Jesus and the disciples according to the Fourth Gospel: With implications for the Fourth Gospel's purpose and the mission of the contemporary church, Eerdmans, Grand Rapids.

Lindars, B., 1990, John, Academic Press, Sheffield.

Martyn, J.L., 1979/1968, History and theology in the Fourth Gospel, 2nd edn., Abingdon, Nashville.

McCall, L., 2005, 'The complexity of intersectionality', Signs: Journal of Women in Culture and Society 30(3), 1771-1800.

Meeks, W., 1993, The origins of Christian morality: The first two centuries, University Press, New Haven.

Seeking, J., 2007, Race discrimination and diversity in South Africa, Centre of Social Science Research, Working paper 194, viewed 13 November 2015, from http:// www.cssr.uct.ac.za/sites/cssr.uct.ac.za/files/pubs/WP194.pdf

Tajfel, H., 1982, 'Introduction', in H. Tajfel (ed.), Social identity and intergroup relations, pp. 1-11, Cambridge University Press, Cambridge.

Tilly, C., 2005, Identities, boundaries and social ties, Paradigm, London.

Thompson, M.M. 1996, 'The historical Jesus and the Johannine Christ', in A Culpepper \& C. Black (eds.), Exploring the gospel of john: In honour of D. Moody Smith, pp. 21-42, Westminster John Knox Press, Louisville.

Tong, C.-K., 2010, Identity and ethnic relations in South East Asia, Racializing Chinese, Springer, London.

Van der Merwe, D.G., 1998, 'John 17: Jesus assigns his mission to his disciples', Scriflag en Kerk 19(1), 115-127.

Waldstein, M., 1990, 'The mission of Jesus and the disciples', Communio: Internationa Catholic Review 17(3), 311-333. 